УДК: 91

\title{
ОСОБО ОХРАНЯЕМЫЕ ПРИРОДНЫЕ ТЕРРИТОРИИ И КОРЕННЫЕ НАРОДЫ: СПОСОБЫ РЕШЕНИЯ КОНФЛИКТОВ В СРАВНЕНИИ МЕЖДУ БРИТАНСКОЙ КОЛУМБИЕЙ (КАНАДА) И ПРИМОРСКИМ КРАЕМ (РОССИЯ)
}

\author{
А.В. Бочарникова \\ Санкт-Петербургский научно-исследовательский центр экологической безопасности \\ Российской академии наук, Санкт-Петербург; Россия \\ Эл.nочта: aleksandra.bocharnikowa@yandex.ru \\ Статья поступила в редакцию 11.02.2020; принята к печати 23.05.2020
}

Целью создания особо охраняемых природных территорий (ООПТ) является сохранение природного наследия. Населяющие их коренные малочисленные народы, занятые охотой, рыболовством и оленеводством, сильно зависят от природных условий. Любые изменения территории, связанные с промышленным воздействием или коммерческой деятельностью, затрагивают экономику коренных народов. При этом зачастую коренное население имеет свою точку зрения на то, как надо сохранять природу. Поэтому между местным населением и администрацией ООПТ часто возникают конфликты. Причинами взаимного недопонимания может быть отсутствие четких границ внутри территории, охраняемой государством, а также то, что местные жители вынуждены покидать охотничьи угодья и лишаться возможности заниматься традиционными промыслами. Более того, местные жители тяжело воспринимают новые ограничения психологически, поскольку «это всегда была территория предков». После организации ООПТ появляются туристы, не знакомые с местными традициями. На территориях проживания коренного населения есть священные места, при посещении которых необходимо соблюдать определенные нормы. Многие проблемы зависят от региона, но есть и общие: незаконные вырубки, браконьерские охота и рыболовство, неконтролируемый туризм. В данной статье рассмотрены более и менее успешные варианты опыта соуправления природными территориями.

Ключевые слова: коренные малочисленные народы, особо охраняемая природная территория, соуправление, традиционное природопользование, соииальные институты.

\section{PROTECTED AREAS AND INDIGENOUS PEOPLES: APPROACHES TO CONFLICTS SOLVING IN BRITISH COLUMBIA (CANADA) AND PRIMORSKIY REGION (RUSSIA) COMPARED}

\author{
A.V. Bocharnikova \\ Saint-Petersburg Research Center of Environmental Safety, the Russian Academy of Sciences, \\ Saint Petersburg, Russia \\ E-mail: aleksandra.bocharnikowa@yandex.ru
}

The aim of establishing of protected areas is the preservation of natural heritage. The small populations of indigenous peoples engaged in hunting, fishing, and reindeer herding are heavily dependent on natural conditions. Any territorial alterations associated with industry and commerce impact the indigenous economy. The indigenous peoples often have their original approaches to nature protection. Therefore, conflicts between the locals and the administration of protected areas happen frequently. The reasons of mutual misunderstanding include the lack of clearly delineated borderlines within protected areas, the necessity for the locals to abandon their hunting territories and constrains imposed on their traditional trades. Moreover, it is often hard for the indigenous peoples to accept emerging restrictions related to what has been ever belonging to their ancestors. After a protected area has been established, it often becomes an attraction for tourists unfamiliar with local traditions. There often sacred places in territories inhabited by the indigenous peoples. Strict rules must be observed by those who visit such places. Many problems are region-specific. Common problems include illegal deforestation, hunting and fishing and uncontrolled tourism. The present paper discusses more and less successful approaches to co-administration of protected areas.

Keywords: indigenous peoples, protected areas, co-administration, traditional nature management, social institutes.

\section{Коренные малочисленные народы и природные ресурсы: трансформация стратегии управления}

Традиционное природопользование коренных народов сильно зависит от ландшафта [23]. Связь этноса и ландшафта определяет, какие отрасли хозяйства развиваются [7]. Любые изменения природы делают традиционное природопользование проблематичным. Ограничения, которые мешают осуществлять традиционную хозяйственную деятельность, часто создают государство и промышленные компании [22].

Развитие традиционного общества определяют неформальные институты: социальные практики, выработанные в результате адаптации к существующим природным и социально-экономическим условиям. Источниками институтов становилось само сообщество, другие народы, а также государство, а сейчас - еще и рынок.

Общими для коренных народов являются следующие институты:

- $\quad$ Коллективное принятие решений

Как правило, все вопросы, которые были связаны с распределением ресурсов и границ, решались коллективно [20]. Традиционное природопользование регулировалось нормами общинного права, в основе которых было представление о том, 
что вся земля является живой [11]. Количество зверя определяли сами охотники, как и выбирали территорию, на которой осуществлялась охота. Все решения принимали на сходе.

- $\quad$ Общая собственность на землю

Поскольку по большей части коренные народы вели кочевой или полукочевой образ жизни, землю считали общей. В.К. Арсеньев, изучая удэгейцев, охарактеризовал земельные отношения следующим образом: «Раздел земли они так же не понимают, как раздел воды и воздуха, которыми пользуются наравне и люди, и звери, и птицы. Кто где хочет, тот там и селится. За последние двадцать пять-тридцать лет часть орочей перекочевала на Хунгари, и никто из удэхейцев, живущих на этой реке, не протестовал против этого. Обратное явление - несколько семей удэхейцев перешли на Копи, и копийские орочи отнеслись к этому так, как будто эти удэхейцы живут здесь исстари» [1, с. 18].

- $\quad$ Ограничения на занятия охотой, рыболовством

Чтобы успешно заниматься охотой, необходимы были знания о животных, об их повадках, например, о территории обитания. Для того чтобы промысел мог осуществляться годами, необходимо было, чтобы охотники контролировали количество животных (точнее, не осуществлялся избыточный промысел) [16]. Для этого на охоту отправлялись в том случае, если закончились запасы $[8,13]$. Запрещено было охотиться во время размножения животных, для чего был промысловый календарь, по которому и ориентировались.

- $\quad$ Наличие священных мест

У коренных народов есть священные места, где запрещен традиционный промысел, а некоторые - нельзя посещать. Именно в таких местах часто происходит размножение животных и нерест рыб [13]. По классификации Г.П. Харючи, существовало несколько категорий святилищ: общенародные, родовые и семейные. Например, на острове Вайгач есть священная роща, которая является общенародным достоянием ненцев [14]. Отдельной категорией священных мест были кладбища. Система верований коренных народов способствовала сохранению биологических ресурсов, получила в научной литературе название «промысловая этика».

- $\quad$ Ограничение на охоту на определенные виды животных

Часто священные места связывали с определенными видами животных, было запрещено на них охотиться. Так, например, у удэгейцев, как и других народов тунгусо-маньчжурской языковой группы, считались священными некоторые виды лягушек [10].

- П П Помысловые ритуальь

Часто проводились ритуалы, связанные с тем, что охотники просили прощения у убитого животного. Например, у удэгейцев, орочей, нанайцев - это медвежий праздник [11].

Таким образом, принятые в обществе правила способствовали сохранению природного разнообразия.

Традиционное природопользование перестает быть неистощительным, когда коренное население вовлекается в рыночные отношения. При занятии традиционным промыслом часто возникает конкуренция с тем населением, которое включено в экономику доминирующего сообщества: появляются коммерческие охота и рыболовство. Основной задачей коммерческого природопользования становится добыть и продать как можно больше зверя или выловить рыбы, в то время как объемы традиционного промысла ограничены потребностями самого сообщества [4].

Как правило, конфликты возникают, когда на территории, где коренные жители занимаются промыслами, появляются предприниматели, которые сами занимаются охотой и рыболовством или приводят туристов. Такое природопользование не предполагает ограничивающих установок и истощает экосистему. Местные жители не могут попасть на территорию, доступ к которой перекрывается шлагбаумами.

Еще одна проблема, которая делает невозможным традиционное природопользование, - это промышленное освоение территорий. В этом случае, так же как когда природопользование становится коммерческим, единственным выходом остается создание особо охраняемых природных территорий (ООПТ) [3].

\section{Зарубежный опыт соуправления территориями}

Во многих зарубежных странах при создании ООПТ политики, представители государственного управления и представители коренных народов стараются достичь компромисса между управлением ООПТ и обычаями коренных народов [20]. Часть проблем, связанных с отношениями между коренным населением и администрацией ООПТ, совпадает с российскими, но, поскольку национальные парки в Северной Америке появились значительно раньше, там сложились свои практики взаимодействия.

На Севере Канады в провинции Юкон существует практика заключения соглашений между общинами коренных народов и правительством [23].

95\% национальных парков Канады расположено там, где проживает коренное население. Однако современная политика по отношению к коренным народам сложилась не сразу. Когда на территории Канады появились англичане, политика стала колонизаторской: природные ресурсы использовались для промышленности. Местные жители были ассимилированы: родной язык был запрещен, дети - отправлены на принудительное обучение в интернате. Эти процессы способствовали вымиранию целых племен. 
Когда в Канаде организовывали ООПТ, группы индейцев оказались вынужденными переселяться. Серьезные изменения в политике в Северной Америке начались со второй половины XX века. В Канаде и США эти процессы происходили по-разному. Когда представители государственной власти начали сотрудничать с индейцами, алеутами и иннуитами, были приняты основополагающие документы [17].

Первый национальный парк в Канаде в окрестностях города Банф создали в 1885 г. На этой территории проживали индейцы племен стоуни, ктунаха, тсутина, кайна, пикани и сиксики. Парк находился на территории провинции Альберта, и его организация была связана с открытием термальных источников. Когда создавали парк, индейцы были вынуждены жить в резервациях. Такое решение вызывало протест, более того, все равно местные жители нарушали режим, проникая на территорию незаконно.

Ярким примером такой политики является история создания морской резервации парка Гуаи Хаанас на островах Шарлотта. Большая часть населения проживает лишь на одном острове - Грэм, хотя всего территория состоит из 200 островов. На этой территории обитают редкие виды животных, в том числе американский черный медведь и горностай [18]. Племя индейцев хайда было когда-то многочисленным, но в результате контактов с колонистами, которые привезли с собой европейские болезни, в конце 1880 г. из 12000 оставалось всего 350. Сейчас по всей Канаде к племени хайда относят себя 2500-3000 человек, которые сохранили разделение на кланы ворона и орла как историческую память. Со времен, когда деревни индейцев находились на островах Шарлотта, сохранились тотемические столбы, на которых осуществлялись захоронения (в концов они были уничтожены католическими миссионерами).

Аборигены занимались охотой, рыболовством и промыслом моллюсков, а зимой строили временные дома. Традиционная культура индейцев хайда была во многом утеряна, отчасти из-за того, что ее представители вымерли, отчасти - в результате ассимиляционной политики государства.

В 1985 г. община индейцев выступила с предложением создать территорию наследия индейцев хайда и оградить ее от вырубок, которые проводились лесопромышленными компаниями. На островах Шарлотта основные вырубки осушествляют японские лесопромышленные компании. Брошенная деревня хайда Станг-Гваи получила статус объекта Всемирного наследия ЮНЕСКО. И только тогда вырубки прекратились на этой территории [18].

Однако правительство Канады решило организовать национальный парк, и процесс его создания сопровождался постоянными протестами индейцев, которых уже оставалось очень мало.

Так описывали очевидцы ${ }^{1}$ процесс создания парка:

«В 1985-м г. вожди оставшихся племен хайда вышли на блокаду на острове Лиэл. На старое видео практически невозможно смотреть без слез. Маленькие, сгорбленные старички и старушки в очках сидят прямо на земле, в дождь, перекрывая собой вход грузовикам на проселочную дорогу. Грузовики не могут проехать за лесом. Вызывают полицию. Индейцам зачитывают их права, грозят двумя годами тюрьмы.

- Два года? Мне уже 100 лет, какая разница, где еще два? А там кофе в тюрьме есть? Если есть кофе, мне нормально.

- Да поймите же, мы это делаем не ради себя. Мы уже старые. Мы ради детей. Если вырубить весь лес, где будут дети жить? Не только наши дети. Даже дети белых людей. На чем будут делать деньги ваши дети, если вы вырубите весь лес?

- Я хочу задать правительству Канады только один вопрос, кто сделал эти острова? Правительство Канады или Бог? Если не правительство Канады, то почему оно их продает как свое?»

В итоге, в результате переговоров южная часть архипелага, которая не была заселена, стала заповедником, в ней было запрещено рубить лес. Это решение было поддержано общиной.

В 1988 г. была создана резервация, но серьезные изменения в политике по отношению к аборигенному населению произошли только в 1993 г.: правительство Канады подписало соглашение с общиной индейцев, которые входили в созданный до этого Совет индейцев племени хайда.

Сейчас островами Шарлотта управляет совместная комиссия по управлению архипелагом. Комиссия состоит из 2 представителей индейцев и двух представителей администрации. Финансовую поддержку оказывает государственная структура - парки Канады. Также была принята Программа наблюдателей хайда - 30 человек местных жителей следят за порядком в национальном парке. На официальном уровне опыт создания резервации на островах Шарлотта является достаточно удачным.

\section{Национальный парк «Бикин» в России}

Проблема отношений коренного населения и администрации ООПТ является актуальной для многих регионов. Существует несколько политических стратегий, которые помогают добиться компромисса. В России, по сравнению с зарубежными странами, опыт создания национальных парков небольшой: самый первый парк «Лосиный остров» был создан только в 1981 г. [3]. Как правило, цели и задачи экономической деятельности коренного населения не совпадают с целями и задачами администрации ООПТ, поскольку жители занимаются охотой, рыболовством и оленеводством, что противоречит режиму ООПТ.

\footnotetext{
${ }^{1}$ http://kitya.livejournal.com/241392.html
} 
Природные условия бассейна реки Бикин и коренное население

Бассейн реки Бикин отличается уникальными природными условиями: на территории верхней и средней части бассейна реки Бикин растут кедрово-широколиственные леса, которые являются редкими доледниковыми лесами Евразии. Сейчас они либо сильно изменены, либо исчезли [2].

В горах Сихотэ-Алинь есть несколько географических зон: горные тундры, заросли кедрового стланика, в нижней и средней частях есть заросли ольховника и рододендрона, ниже- еловые и пихтово-еловые леса, долинные леса, горные лиственные и мелколиственные леса [15].

В лесах можно найти редкие виды растений, которые имеют лекарственное значение: аралия, лимонник, элеутерококк, амурский бархат. В бассейне реки Бикин обитают животные более 50 видов, в том числе 16 хищных, таких как енотовидная собака, амурский барсук, американская норка, соболь, колонок, выдра, бурый и гималайский медведь. Много редких и краснокнижных видов [15].

Бассейн реки Бикин - территория традиционного проживания удэгейцев и нанайцев.

Жизнь коренного населения прямо связана с природными условиями, а отношение к природе в течение истории претерпевало изменения. По классификации культурно-хозяйственных типов М.В. Левина и Н.Н. Чебоксарова, удэгейцы относятся к «таежным охотникам и рыболовам» [9], для которых главное значение имела охота, а рыболовство вспомогательное.

Еще в середине XIX века удэгейцы и нанайцы стали селиться на труднодоступных протоках, что способствовало сохранению традиционных видов деятельности. Удэгейцы бассейна реки Бикин охотились на оленя, кабана, лося, росомаху, енотовидную собаку и колонка. Соболь у удэгейцев не был традиционным видом охотничьего промысла, на него стали охотиться после контактов с русскими и китайцами [12].

Помимо охоты и рыболовства население, проживающее в бассейне реки Бикин, занималось собирательством: они собирали черемшу, дикий лук, свежие коренья папоротника, коренья дикой лилии, мяту, подорожник. Из ягод собирали жимолость, голубику, красную смородину, клюкву, шиповник и калину [12].

\section{Традииионные институичи удэгейцев бассейна реки Бикин и их трансформация} сообщество.

Отношение коренного населения к природе определялось некоторыми правилами, которые выработало аборигенное

- Старались добывать не больше, чем требовалось для стабильного существования сообщества и сохранения природного равновесия. Часть правил сохранилась и по настоящее время: «Когда находишься в тайге, то для еды бьешь коз, их хватит поесть. А изюбра бьешь, когда едешь домой, тогда уже его делишь» [6, с. 68]. Похожие запреты касались рыболовства и собирательства.

- На промысле часто проводили ритуалы. Удэгейцы проводили «медвежий праздник»: после того как убивали медведя, его тушу поворачивали головой на запад, а свежевали ее все участники охоты. До XX века переодевались в праздничную одежду, и было не принято говорить о том, что собираешься на охоту, иначе добычи не будет [12, с. 87].

- Запреты на охоту на определенные виды животных. У удэгейцев была запрещена охота на тигра, которого считали предком; определенные ограничения касались охоты на медведя. Еще в XIX веке был обычай кровной мести тигру, если он на кого-то нападал. Если человек на охоте встречал тигра, то добычу оставляли тигру.

- Были священные деревья. У удэгейцев священные деревья нельзя было срубать, и запрещено было загрязнять места около них. Благодаря традиционным представлениям сохранялись определенные виды деревьев. К ним относят большой ильм, ясень, дух и пихту [10, с. 73-74].

- Зонирование территории. Существовали священные места, на которых нельзя было заниматься охотой и рыболовством. Вся территория делилась на промысловую и запретную. Благодаря этому священные места становились местом размножения животных, что позволяло восстанавливать популяции. Запретным местом являлась священная гора Сивантай. Запрещено было заниматься промыслом также на родовых кладбищах [11].

- Санитарно-экологические правила. Существовал запрет выкидывать внутренности в реку при разделывании туш животных.

- Гендерное разделение труда. В традиционном обществе общественный строй был патриархальный, существовало четкое разделение труда между мужчиной и женщиной. Мужчины занимались охотой и рыболовством, а на женщину возлагалась вся домашняя работа - работа около юрты и шитье одежды.

Серьезные изменения институтов, которые регулировали традиционное природопользование удэгейцев, начались с включением их в рыночные отношения. До активных контактов с русскими и китайцами преобладали традиционные методы охоты: оружием были копье, луки, использовались петли и ловушки. С появлением огнестрельного оружия охота интенсифицировалась, и ограничение на добычу сверх необходимой перестало действовать. Если раньше преобладала мясная охота, то после активного взаимодействия с китайцами, русскими и корейцами главной стала пушная охота, в особенности охота на соболя. Однако часть правил сохраняется даже после вовлечения местного населения в рыночные отношения: запрет охоты на тигра, наличие священных мест и санитарно-экологические правила [4]. 
В советское время процесс разрушения традиционных институтов был приостановлен, поскольку не было рынка сбыта. Зонирование территории осуществлялось государством, также у коренных народов появлялись новые отрасли, например сельское хозяйство [5].

В постсоветский период отношение коренного населения к природе очень сильно изменилось: поскольку не было легального рынка сбыта, активно развивался черный рынок, а традиционные институты, которые защищали природу от избыточного потребления, стали вытесняться рыночными. В особенности спросом пользовались продукты для восточной медицины - лапы и желчь медведя, струя кабарги, женьшень.

Запрет на убийство тигра оставался. Но в советское время многие промысловые праздники не проводились, поскольку были запрещены [4].

До создания национального парка «Бикин» охота, рыболовство и собирательство оставались основными занятиями, например, жителей поселка Красный Яр. Деление участков сохранилось такое же, как и в советское время. В 2014 г. по учету, который вела община «Тигр», официально в промысловом сезоне принимал участие 91 охотник. Пушная охота включала промысел соболя, норки и белки, при этом охотники должны были сдавать пушнину в общину, и далеко не всегда удавалось добыть нужное количество зверя. Местные охотники могли сдавать пушнину помимо общины скупщикам по значительно более высокой цене [5].

Новой отраслью, в которую были активно вовлечены коренные жители, стал туризм: работая проводниками, жители смогли в 2014 г. зарабатывать по 3000-4000 рублей за один день ${ }^{2}$. Более того, такой туризм никак не регулировался.

Таким образом, с вовлечением в рыночные отношения традиционные институты разрушались и заменялись рыночными.

Еще одной угрозой для природных экосистем бассейна реки Бикин стали вырубки. Постоянно на освоение территории претендовали лесопромышленные компании, а местные жители объединялись с представителями общественных организаций, как экологических, так и коренных малочисленных народов Севера, в борьбе против вырубок [15].

В 1980-1990 гг. произошел значительный рост общественных объединений, в том числе была создана Ассоциация коренных малочисленных народов Севера, Сибири и Дальнего Востока.

В Пожарском районе Приморского края активные вырубки начались еще в 1960-х гг., однако в бассейне реки Бикин лесопромышленные компании появились только в 1970-1980 гг. После вырубки леса в Красноармейском районе численность удэгейцев сократилась до нескольких семей, что показывает прямую связь между истощением среды и аборигенными народами [15].

Конфронтация коренных жителей и лесопромышленных компаний продолжалась с 1980 по 2011 г. Источниками новых институтов были жители Бикина, государственные структуры и экологические организации. Первый серьезный конфликт, который способствовал объединению жителей Краснояровского поселения, произошел в 1989 г. с компанией «Хендэ». Протесты носили широкий характер, в них участвовали жители поселка, в том числе коренное население, а также Ассоциация коренных малочисленных народов Севера, Сибири и Дальнего Востока и представители экологических неправительственных организаций - WWF (World Wildlife Fund - Фонд защиты дикой природы), Friend of Earth International (Друзья Земли), ученые и журналисты.

В 1998 г. был образован заказник «Верхнебикинский», однако его создание не давало гарантий, что вырубки не будут производиться. Более того, организация территории повлекла ограничение на использование механического транспорта для местных жителей, добиравшихся до своих угодий (добираться можно было только на лодке) [4].

В 2003 г. ЗАО «Приморские лесопромышленники» предлагало уменьшить площадь Верхнебикинского заказника. Последний серьезный конфликт произошел в 2011 г. с компанией «ЛесЭкспорт».

На первом этапе протесты часто носили нелегитимный характер: они включали пикеты и перекрытие дорог; на втором, начиная с 2000-х, решения принимались на сходах, и велись переговоры.

\section{Предпосылки организаџии наџионального парка «Бикин»}

Было несколько причин, которые сделали необходимым создание ООПТ федерального значения:

- нагрузка на экосистему, которая была связана, в том числе, и с развитием туризма;

- угроза вырубок;

- браконьерство, в котором участвовали как местные жители, так и приезжие, особенно в связи со сбытом пушнины и продукции для восточной медицины;

- коммерциализация традиционного хозяйства коренных народов;

- географическое положение и уникальная природа;

- $\quad$ требование экологических организаций создать ООПТ федерального значения [5].

\footnotetext{
${ }^{2}$ По полевым данным автора.
} 
Организация национального парка «Бикин»: от конфликта к соуправлению

В 2015 г., когда было принято решение о создании национального парка «Бикин», традиционные институты коренных малочисленных народов стали заменяться рыночными. Перед созданием парка появилось множество проблем, которые были связаны с коренным населением.

Большая часть населения поселка Красный Яр, на границе которой создавали национальный парк, работала в общине «Тигр», в общину можно было сдавать продукцию, но по меньшей цене, чем скупщикам в Китай и Корею. Природопользование становилось не традиционным, а коммерческим. Помимо этого, на территории Пожарского района осуществлялись нелегальные вырубки, которые никак не контролировались. Еще одной проблемой стал нерегулируемый туризм, который был источником заработка для местных жителей. Больше всего использовались участки, наиболее близкие к деревне.

Решением этих проблем стало создание национального парка, который, в соответствии с определением в законодательстве, может использоваться не только в природоохранных целях, но и для регулируемого туризма.

Сначала национальный парк создавали стандартным путем, сразу же после решения правительства Российской Федерации, однако это вызвало протест среди местного населения. В 2012 г. община «Тигр», в которой работали местные охотники, направила в правительство обращение против создания любой ООПТ федерального значения. После чего была создана специальная группа, которая состояла из местных жителей и представителей общественных организаций, которые потребовали создать Совет из коренных народов, выделить рабочие места в штате парка и обширную территорию традиционного природопользования. Эти требования были выполнены.

Национальный парк «Бикин» был создан 3 ноября 2015 г. Постановлением Правительства Российской Федерации. Его территория составила 1,1 млн га. Он стал первой территорией, в уставе которой написано, что защита окружающей среды является целью ее организации ${ }^{3}$. Для регулирования деятельности был создан Совет коренных народов, в состав которых входят старейшины. Совет коренных народов действует при администрации парка.

Проект организации национального парка вызвал раскол в местном сообществе: часть поддерживала создание национального парка, часть - выступала против. Основной причиной негативного отношения к этой идее были опасения жителей, что они не смогут продолжать заниматься традиционной хозяйственной деятельностью [3]. Также не верили, что администрация выполнит свои обязательства. Условиями создания ООПТ были переговоры с местными жителями. Таким образом, создание национального парка «Бикин» можно считать примером успешного соуправления.

\section{Национальный парк «Бикин» и «Удэгейская легенда»}

При создании национального парка «Бикин» в 2015 г. было еще и предложение создать территорию традиционного природопользования федерального значения.

Когда жителям поселка Красный Яр предложили создать национальный парк, большая их часть выступила против, сославшись на отрицательный опыт парка «Удэгейская легенда». Этот национальный парк расположен в соседнем Красноармейском районе Приморского края, который также исторически был территорией проживания удэгейцев, но эта территория всегда была менее изолированной, чем в бассейне реки Бикин. Однако, в отличие от Пожарского района, Красноармейский район был намного сильнее затронут лесозаготовками, а удэгейцы и нанайцы смешаны с русскими, украинцами и белорусами.

В 2011 г. автор проводила интервью с охотоведом общины «Тигр», которая существовала до организации парка. Вот его свидетельства: «Я участвовал в разработке всех документов по территориям традиционного природопользования и посещал некоторые национальные парки, где проживают коренные малочисленные народы. И, как показывает практика, в созданном четыре назад национальном парке “Удэгейская легенда” в Красноармейском районе до сих пор идет война между администрацией парка и коренными народами. Сначала идут навстречу, когда создают парк. В “Удэгейской легенде” осталась горстка удэгейцев, несколько десятков человек, община находится на этой территории. У них тоже было небольшое охотничье хозяйство 30 тысяч га, а общая площадь национального парка, который создали, где-то 90 тысяч га. Национальный парк создали. Прислала Москва начальника, и всё - у них началась война: поставили шлагбаум, в лес идти нельзя, охотой нельзя заниматься, просто выделили им кусочек - этой общине. Они судились. Судились, наверное, года два, в итоге выиграли этот суд, признали постановление о создании национального парка незаконным, обязали отдать им обратно все (охотничью территорию). В общем, вот такая вот практика везде» [5]. Эта обширная цитата характеризует проблему отношений местного населения и администрации.

Национальный парк «Удэгейская легенда» был создан 9 июня 2007 г. в пределах Красноармейского района Приморского края. Он находится на территории бассейна реки Большая Уссурка и Арму. Население составляет всего 112 человек, состоит из удэгейцев, нанайцев и русских.

\footnotetext{
${ }^{3}$ Устав Федерального государственного бюджетного учреждения «Национальный парк «Бикин», утверждено Минприроды России от 19.04.2016. М.; 2016.
} 
В буферной зоне расположены поселки Дальний Кут (230 человек), Дерсу (37 человек) и Островной (2 жителя). В Красноармейском районе население смешанное, а представителей коренных народов значительно меньше, чем в поселке Красный Яр.

Вокруг территории национального парка землю арендуют лесозаготовительные предприятия, что делает неэффективной защиту природы даже при создании ООПТ федерального значения. Большая часть населения района работает в лесозаготовительной отрасли. До организации ООПТ были проведены общественные слушания, в ходе которых планировалось выделить рабочие места для местных жителей, однако это обещание не было выполнено: за 9 лет было трудоустроено только 8 человек из коренных народов, а сейчас остался один. Штат парка составляют приезжие, более того, территория недостаточно защищена от претензий лесозаготовительных компаний.

Между администрацией парка и коренными жителями установилось взаимное недоверие, более того, местные жители не были вовлечены в управление парком. Реальной проблемой является то, что разделение территории парка на зоны существует на бумаге, сами границы парка четко не определены. Причем очень часто о том, что они нарушили границу зоны, охотники узнают уже задним числом, когда их штрафуют за охоту в неположенном месте или за то, что они поехали за дровами. Одно из самых главных условий установления доверия между местными жителями и администрацией парка - это когда границы четко установлены и понятны для всех [5].

В 2009 г. община «Удэге», границы который находятся на территории парка, подала в суд на администрацию национального парка за нарушение прав коренных народов. Этот конфликт отразился в СМИ федерального значения: тогда удэгейцев обвинили в том, что они сотрудничают с лесорубами. В конечном счете община выиграла суд, а территория более 20 тыс. га была выведена в пользу общины. Проблемой стало то, что территория скорее использовалась для вырубок, которые приносили основной доход для местных жителей.

Основными причинами того, что коренное население не участвовало в процессе соуправления, были конфликт с администрацией, отсутствие гарантий прав коренных народов в документах, отсутствие активистов среди местного населения и то, что в Красноармейском районе больше всего смешанного населения.

\section{Заключение}

Исторически традиционное сообщество выработало ряд практик, которые были направлены на сохранение природы. Все необходимые решения принимали коллективно, не было частной собственности на землю. Существовали ограничения, связанные с промыслом: старались добывать не больше, чем требовалось для того, чтобы обеспечить семью. Также запрещено было охотиться (а также заниматься другой хозяйственной деятельностью) на священных местах, были определенные виды животных и растений, которые считались священными. Такие практики подкреплялись традиционной системой верований. Все эти правила трансформируются, когда народы вовлекаются в рыночные отношения. Более того, на территории часто возникают конфликты с промышленными компаниями, а также теми, кто занят коммерческими охотой и рыболовством. Единственным выходом становится создание ООПТ, но в этом случае необходимо сочетать интересы местного населения с природоохранными.

Первый опыт создания национальных парков Канады был неудачным: местные жители были вынуждены переселиться в резервации. На островах Шарлотты создана морская резервация, управление островом осуществляется Комиссией, состоящей из администрации и представителей коренного населения.

У коренного населения бассейна реки Бикин также сложились традиционные институции, поскольку экономика была связана с природой. Рыночные отношения, другие народы и государства способствовали трансформации традиционных институтов. Угрозами для природы стали вырубки и то, что само природопользование стало коммерческим, на территории стал развиваться нерегулируемый туризм. При организации национального парка «Бикин» компромисс с местным населением был достигнут, поскольку был создан Совет коренных народов, в то же время в «Удэгейской легенде» конфликт между администрацией парка и коренным населением так и остался.

\section{Список русскоязычной литературы}

\section{Литература}

1. Арсеньев ВК. Лесные люди удэхейцы. Владивосток: Книжное дело; 1926.

2. Бочарников ВН, Глущенко ЮН, Михайлов КЕ, Егидарев ЕГ. Национальный парк «Бикин». Биота и среда заповедников Дальнего Востока. 2016; (1):3-24.

3. Бочарникова АВ. Коренные народы и особо охраняемые природные территории: опыт соуправления природными ресурсами. М.: ЦС КМНС; 2017.

4. Бочарникова АВ. Трансформация институтов, регулирующих традиционное природопользование (на примере удэгейцев бассейна реки Бикин). Известия РГО. 2017;149(3):73-91.

5. Бочарникова АВ. Влияние трансформации институтов коренных народов Дальнего Востока на изменение политики в сфере традиционного природопользования в Пожарском районе Приморского края. Вестник ПсковГУ. 2019; (15):33-43.

6. Звиденная ОО, Новикова НИ. Удэгейцы: охотники и собиратели реки Бикин. М.: Стратегия; 2010.

7. Клоков КБ. Традиционное природопользование народов Севера: концепция сохранения и развития. Этногеографические и этноэкологические исследования. 1997;(5) 3-44. 
8. Крупник ИИ. Древние эскимосские китобои в Арктике: «бойни детенышей» или интуитивная экология? В кн.: Экологические аспекты палеоантропологических и археологических реконструкций. М.; 1992. С. 161-78.

9. Левин МГ, Чебоксаров НН. Хозяйство-культурные типы и историко-этнографические области. М.: Советская энциклопедия; 1955. С. 3-17.

10. Подмаскин ВВ. Проблема этногенеза удэгейцев. В кн.: Проблемы историко-культурных связей народов Дальнего Востока: Сборник науч. трудов ИИАЭ НДВ АН СССР. Владивосток; 1989. С. $72-9$.

11. Старцев АФ. Культура и быт удэгейцев (вторая половина XIX-XX вв.). Владивосток: Дальнаука; 2005.

12. Старцев АФ. История социально-экономического и культурного развития удэгейцев (середина XIX-XX вв.). Владивосток: Издательство Дальневосточного университета; 2000.

13. Теребихин НМ. Сакральная экология и традиционные знания народов Севера (к постановке проблемы). Экология человека. 2014;(8):57-9.

14. Харючи ГП. Природа в традиционном мировоззрении ненцев. СПб.: Историческая иллюстрация; 2012.

15. Экосистема бассейна реки Бикин: Среда. Человек. Управление. Владивосток: ДВО РАН; 1997.

\section{Общий список литературы/Reference list}

1. Arsenyev VK. Lesnye Liudi Udekheytsy. Vladivostok: Knizhnoye Delo; 1926. (In Russ.)

2. Bocharnikov VN, Glushhenko YuN, Mikhaylov KYe, Yegidarev EG. [National Park "Bikin”]. Biota i Sreda Zapovednikov Dalnego Vostoka. 2016;(1):3-24. (In Russ.)

3. Bocharnikova AV. Korennye Narody i Osobo Okhraniayemye Prirodnye Territorii: Opyt Soupravleniya Prirodnymi Resursami. Moscow: CS KMNS; 2017. (In Russ.)

4. Bocharnikova AV. [Transformation of regulatory institutes related to traditional land use as it occurs among Udege people of Bisin River basin]. Izvestiya RGO. 2017;149(3):73-91. (In Russ.)

5. Bocharnikova AV. [The impact of transformation of institutes of indigenous people of the Far East on changes in policies related to traditional land use in Pozharskiy District of Primoskiy Region]. Vestnik PskovGU. 2019;(15):33-43. (In Russ.)

6. Zvidennaya OO, Novikova NI. Udegeytsy: Okhotniki i Sobirateli Reki Bikin. Moscow: Strategiya; 2010. (In Russ.)

7. Klokov KB. [Traditional land use among Northern peoples: A concept of preservation and development]. Etnogeograficheskiye i Etnoekologicheskiye Issledovaniya. 1997;(5):3-44. (In Russ.)

8. Krupnik II. [Ancient Eskimo whalers in the Arctic: Calf slaughtering or intuitive ecology?]. In: Ekologichaskiye Aspekty Paleoantropologicheskikh i Arkheologicheskikh Rekonstrutsiy. Moscow; 1992. P. 161-78. (In Russ.)

9. Levin MG, Cheboksarov NN. Khoziaystvo-Kulturnye Tipy i Istoriko-Etnograficheskye Oblasti. Moscow: Sovetskaya Ensyklopedia: 1955. P. 3-17. (In Russ.)

10. Podmaskin VV. [The problem of ethnogeny of Udege people]. In: Problemy Istoriko-Kulturnykh Sviazey Narodov Dalnego Vostoka. Vladivostok; 1989. P. 72-9. (In Russ.)

11. Startsev AF. Kultura i Byt Udegeytsev (Vtoraya Polovina XIX-XX vv.). Vladivostok: Dalnauka; 2005. (In Russ.)

12. Startsev AF. Istoriya Sotsialno-Ekonomicheskogo i Kulturnogo Razvitiya Udjegeytsv (Seredina XIX-XX vv.). Vladivostok: Izdatelstvo Dalnevostochnogo Universiteta; 2000. (In Russ.)

13. Terebikhin NM. [Sacral ecology and traditional law of the Northern Peoples: Posing the problem]. Ekologiya Cheloveka. 2014;(8):57-9. (In Russ.)

14. Khariuchi GP. Priroda v Traditsionnom Mirovozzrenii Nentsev. Saint Petersburg: Istoricheskaya Illjustratsiya: 2012. (In Russ.)

15. Ekosistema Basseyna Reki Bikin Sreda Chelovek Upravleniye. Vladivostok: DVO RAN; 1997. (In Russ.)

16. Frankel S. Traditional Knowledge, Indigenous Peoples, and Local Communities. In: The Oxford Handbook of Intellectual Property Law. DOI: 10.1093/oxfordhb/9780198758457.013.33

17. Gladu JP, Brubacher D, Meek C. Aboriginal experiences in Canada - parks and protected areas. Boreal Footprint Project, Taiga Rescue Network; 2003.

18. Gwaii H. National Marine Conservation Area Reserve and Haida Heritage Site Interim Management Plan and Zoning Plan. Canada, 2010.

19. Nepal S. Involving indigenous peoples in protected area management: Comparative perspectives from Nepal, Thailand, and China. Environ Management. 2002;(30):0748-0763.

20. Rassip W, Yunupingu D et al. Indigenous protected areas in Sea Country: Indigenous-driven collaborative marine protected areas in Australia. Aquatic Conserv Mar Freshw Ecosyst. 2019;(S2):1-14. doi: 10.1002/aqc.3052.

21. Sillitoe P. Indigenous peoples, national parks, and protected Areas: A new paradigm linking conservation, culture, and rights. Mountain Res Develop. 2015; 35(3):311-2.

22. Stevens SF. Conservation through Cultural Survival: Indigenous Peoples and Protected Areas. Washington DC: Island Press; 1997.

23. Zurba M, Beazley KF, English E, Buchmann-Duck J. Indigenous protected and conserved areas (IPCAs), Aichi Target 11 and Canada’s Pathway to Target 1: Focusing conservation on reconciliation. Land. 2019;8;10; doi:10.3390/land8010010. 